\title{
STRESS-CORROSION CRACKING OF A URANIUM 6-WEIGHT PERCENT NIOBIUM ALLOY
}

\author{
Research and Development, \\ CHEMISTRY-COMPONENT DEVELOPMENT GROUP \\ Robert L. Kochen \\ Richard Mah
}

PHYSICAL METALLURGY GROUP

Ross J. Jackson

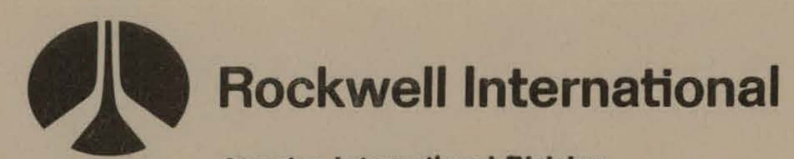
Atomics International Division
Rocky Flats Plant
P.O. Box 464
Golden, Colorado 80401
U.S. ENERGY RESEARCH AND DEVELOPMENT ADMINISTRATION
Prepared under Dow Chemical Contract AT (29-1)-1106
Printed under Contract E(29-2)-3533




\section{DISCLAIMER}

This report was prepared as an account of work sponsored by an agency of the United States Government. Neither the United States Government nor any agency Thereof, nor any of their employees, makes any warranty, express or implied, or assumes any legal liability or responsibility for the accuracy, completeness, or usefulness of any information, apparatus, product, or process disclosed, or represents that its use would not infringe privately owned rights. Reference herein to any specific commercial product, process, or service by trade name, trademark, manufacturer, or otherwise does not necessarily constitute or imply its endorsement, recommendation, or favoring by the United States Government or any agency thereof. The views and opinions of authors expressed herein do not necessarily state or reflect those of the United States Government or any agency thereof. 


\section{DISCLAIMER}

Portions of this document may be illegible in electronic image products. Images are produced from the best available original document. 


\section{LEGAL NOTICE}

This report was prepared as an account of work sponsored by the United States Government. Neither the United States nor the Energy Research and Development Administration, nor any of their employees, nor any of their contractors, subcontractors, or their employees, makes any warranty, expressed or implied, or assumes any legal liability or responsibility for the accuracy, completeness or usefulness of any information, apparatus, product or process disclosed, or represents that its use would not infringe privately owned rights.

Printed in the United States of America

Available from the

National Technical Information Service

U. S. Department of Commerce

Springfield, Virginia 22161

Price: Printed Copy $\$ 4.00$ Microfiche $\$ 2.25$ 
Research and Development, CHEMISTRY-COMPONENT DEVELOPMENT GROUP

Robert L. Kochen

Richard Mah

\section{PHYSICAL METALLURGY GROUP}

Ross J. Jackson

ROCKWELL INTERNATIONAL ATOMICS INTERNATIONAL DIVISION ROCKY FLATS PLANT P.O. $80 \times 464$ GOLDEN, COLORADO 80401

Prepared under Dow Chemical Contract AT (29-1)-1106

Printed under Contract E(29-2)-3533 for the Albuquerque Operations Office U.S. Energy Research and Development Administration 


\section{THIS PAGE \\ WAS INTENTIONALLY \\ LEFT BLANK}




\section{CONTENTS}

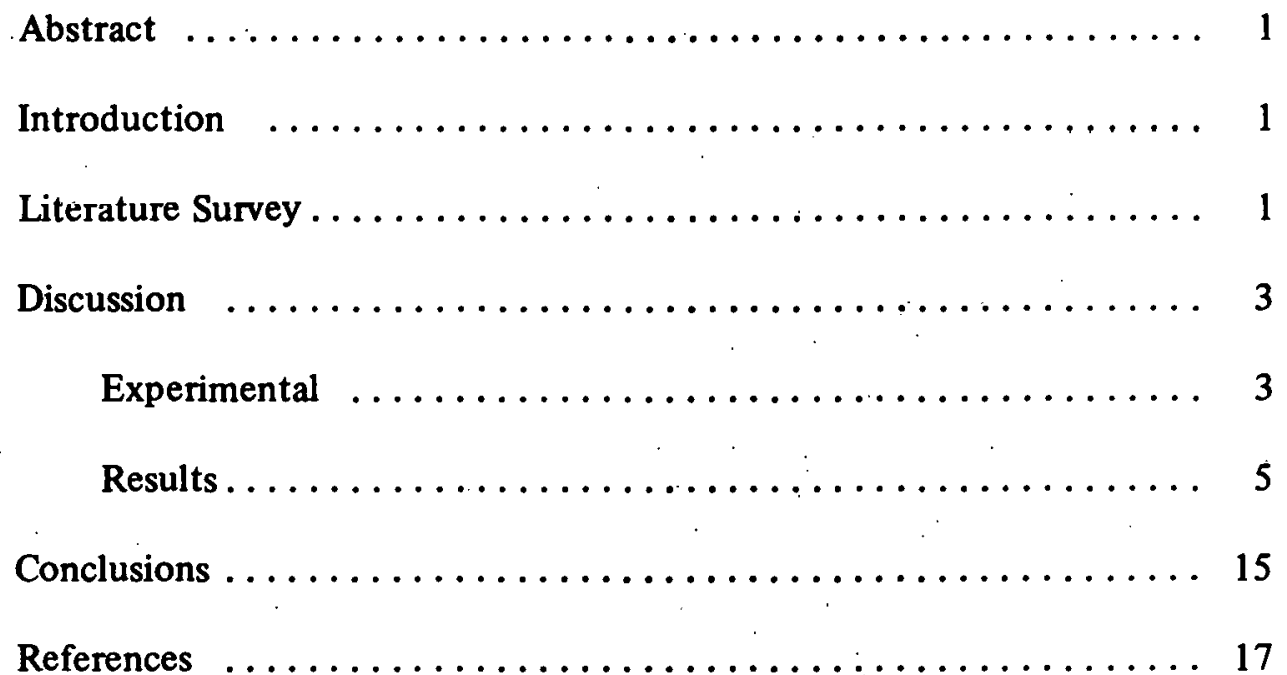


RFP-2429

\section{THIS PAGE \\ WAS INTENTIONALLY \\ LEFT BLANK}




\section{ACKNOWLEDGM E N T S}

Appreciation is expressed to members of the two Research and Development groups providing support on the project. Richard Mah has since transferred to the Research Department of the C. F. Braun Company, Alhambra, California 91802. 


\section{THIS PAGE \\ WAS INTENTIONALLY \\ LEFT BLANK}




\title{
STRESS-CORROSION CRACKING OF A \\ URANIUM 6-WEIGHT PERCENT NIOBIUM ALLOY
}

\author{
Robert L. Kochen, Richard Mah, and Ross J. Jackson
}

Abstract. The stress-corrosion cracking (SCC) behavior of the uranium 6-weight percent niobium (U 6-wt \% Nb) alloy in three different heat-treated conditions was investigated. The three heat treatments were: (a) solution quenched (the nonaged condition); (b) solution quenched and aged 6 hours at $250^{\circ} \mathrm{C}$ (the underaged condition); and (c) solution quenched and aged 80 minutes at $600{ }^{\circ} \mathrm{C}$ (the overaged condition). The SCC tests utilized smooth, dead-weight loaded, static tensile specimens exposed to nitrogen-saturated or oxygensaturated water containing 50 parts per million (ppm) chloride ions. The alloy in the solutionquenched condition was not susceptible to SCC when loaded to 90 percent of yield strength in either the oxygen or nitrogen-saturated chloride solutions. The underaged material ( 6 hours at $250^{\circ} \mathrm{C}$ ) was susceptible to SCC in oxygen or nitrogen-saturated water containing $50 \mathrm{ppm}$ chloride ions. The underaged material was more susceptible to cracking in the oxygen-saturated solution than in the nitrogen-saturated solutions. The SCC in the underaged material proceeded by a principally intercrystalline fracture mode with the overload condition being principally transgranular. The overaged material also exhibited SCC, but to a lesser extent than the underaged material. Here again, cracking was more pronounced in the oxygen-saturated solution than in the nitrogen-saturated solution. The overaged material fractured by a combined SCC mode and mechanicalcracking mode, i.e., stress-corrosion cracks were growing at the same time corrosion was reducing the cross-sectional area of the specimen. The importance of knowing alloy characteristics relates to considerations of design, environmental behavior, and economics.

\section{INTRODUCTION}

The uranium 6-weight percent niobium (U 6-wt \% Nb) alloy is an economical, high density [17.4 grams per cubic centimetre $\left(\mathrm{g} / \mathrm{cm}^{3}\right)$ ], engineering alloy possessing good corrosion resistance. The alloy can be solution-quenched from the single-phase gamma region $\left(750\right.$ to $\left.1100^{\circ} \mathrm{C}\right)$ to yield a supersaturated, single-phase, monoclinic, alpha-prime solid solution. The solution-quenched alloy is in the soft condition and can be strengthened by aging in the alpha plus gamma $_{2}\left(\alpha+\lambda_{2}\right)$ two-phase region $\left(150\right.$ to $\left.640^{\circ} \mathrm{C}\right)$. The equilibrium phase relationships involved are discussed by Rogers et al. (1) and by Pfeil et al. (2). ${ }^{1}$ The nonequilibrium phase relationships are given by Anagostidis et al. (3), Tangri and Chaudhuri (4), D'Amato et al. (5) and Jackson (6). The strengths of the quenched and aged alloys are discussed by Jackson and Miley (7). The corrosion behavior of the alloy is discussed by Waber ( 8 ) and by Macki and Kochen $(9,10)$.

Uranium alloys, as a general rule, are subject to stress-corrosion cracking in several environments, including air, especially in the strengthened (aged) conditions. Minimum yield strengths of 120,000 psi [ 840 megapascals $(\mathrm{MPa})$ ] and elongations of 10 percent or greater were required. The strength requirements could be achieved by solution quenching from the gamma-phase field followed by either underaging or overaging in the $\alpha+\lambda_{2}$ twophase region. The $\mathrm{U} 6-\mathrm{wt} \% \mathrm{Nb}$ alloy in this application also had to have maximum resistance to stress-corrosion cracking. Thus, this study was to evaluate and compare stress-corrosion properties of the underaged and overaged material. The solution-quenched material was also evaluated, since certain design modifications did not require the high strengths of the aged alloy.

\section{LITERATURE SURVEY}

Several reports (11 through 22) are available on the stress-corrosion behavior of uranium-niobium

\footnotetext{
${ }^{1}$ Numerals in parentheses relate to references at end of text.
} 
alloys. Tragert (11) sought the SCC mechanism for several reactor materials (including $\mathrm{U}-\mathrm{Nb}$ alloys). Orman (12) developed a rapid test for determining susceptibility to SCC and applied the test to several alloys, one of which was the U 6-wt \% $\mathrm{Nb}$ alloy. Stephenson (13) studied metallurgical and electrochemical variables on the initiation phase of stress-corrosion cracking for the U 4.5-, U 6.5-, and $\mathrm{U} 8.5$-wt $\% \mathrm{Nb}$ alloys. Bend specimens, immersed in aqueous solutions and held at constant potentials, were used to investigate the stresscorrosion crack initiation characteristics of the three $\mathrm{U}-\mathrm{Nb}$ alloys.

Magnani et al. $(14,18)$ looked at the effect of chloride ions on the cracking behavior of the U 4.5-wt \% Nb alloy. A fracture mechanics approach to the problem showed that chloride-ion concentration strongly affects both the crack velocity and the fracture mode. Three concentrations were investigated: $<2,50$, and 500 parts per million (ppm) chloride ions. For the $<2$ and $50 \mathrm{ppm} \mathrm{Cl}^{-}$ solutions, stress-intensity thresholds of 14 to 17 $\mathrm{ksi}$-(inch $)^{1 / 2}\left[15\right.$ to $\left.19 \mathrm{MPa}-(\mathrm{m})^{1 / 2}\right]$ were observed. At the $500 \mathrm{ppm} \mathrm{Cl}^{-}$level, stress-corrosion cracking was observed without the application of stress. This was attributed to corrosion-product wedging. Magnani et al. (15) in another report looked at the stress-corrosion cracking behavior of tungstenfilament-reinforced U 4.5-wt \% Nb alloy in 100 percent relative-humidity air. Units for fracture toughness value are expressed in thousand pounds per square inch-(inch $)^{1 / 2}\left[\right.$ ksi-(inch $\left.^{1 / 2}\right]$ and translate for metric use to megapascals-(metre) $)^{1 / 2}$ $\left[\mathrm{MPa}-(\mathrm{m})^{1 / 2}\right]$.

McLaughlen et al. (16) studied the effect of aging on the susceptibility of the $\mathrm{U} 5$-wt $\% \mathrm{Nb}$ alloy to stress-corrosion cracking. Their results showed that optimum resistance to the initiation of stresscorrosion cracks can be obtained by aging above $550{ }^{\circ} \mathrm{C}$. The aging treatments in this range produced a microstructure resistant to stress-corrosion cracking and the alloy also had good tensile and ductility properties measured in air. For example, an alloy aged for 8 hours at $600{ }^{\circ} \mathrm{C}$ possessed an ultimate tensile strength of $160 \mathrm{ksi}[1,120$ megapascals (MPa)] with 17 percent elongation."

Magnani (17) reported on the effects of environment on the cracking behavior of several uranium alloys.
His results showed that all of the alloys (including $\mathrm{U}$ 4.5-wt \% Nb) stress-corrosion cracked in laboratory air and that aqueous solutions containing chloride ions were considerably more hostile. Magnani indicates that the observed transgranular cracking is caused by a two-stage mechanical stress-corrosion cracking mechanism, involving either oxidation at the crack tip and then rupture of the film or the base material below the film or the absorption of oxygen at the crack tip and then rupture of the weakened matrix material.

Macki and Kochen (19) studied the stress-corrosion cracking behavior of the U 4.2-wt \% Nb alloy aged 80 hours at $260^{\circ} \mathrm{C}$. Smooth four-point bend SCC tests and smooth static-tensile SCC tests were used. The results of this study showed that the aged U 4.2-wt \% Nh alloy was susceptible to SCC when stressed and exposed to water containing oxygen and chloride ions. The stress-corrosion cracks which nucleated in the aqueous chloride environments proceeded by an intergranular SCC fracture mode. No failures were observed in dry air containing less than $200 \mathrm{ppm}$ moisture or in 100 percent relative humidity air. The surface tensile stress required for SCC was less than 20,000 pounds per square inch (psi) (140 MPa) in oxygen-saturated water containing $50 \mathrm{ppm}$ chloride ions.

Magnani et al. (20) observed the stress-corrosion cracking behavior of $\mathrm{U} 4.5$-wt $\% \mathrm{Nb}$ in about 10 percent relative humidity air using side-grooved, tapered, dnuble-cantilevered-beam specimens. Crack propagation was monitored using crack opcning displacement gauges and acoustic emissinn detection techniques. The thrcshold stress intensity for stress-corrosion cracking was determined to be approximately $20 \mathrm{ksi}$-(inoh) $)^{1 / 2}\left[22 \mathrm{MPa}-(\mathrm{m})^{1 / 2}\right]$ and the plane strain fracture toughness approximately $50 \mathrm{ksi}-(\text { inch })^{1 / 2}\left[55 \mathrm{MPa}-(\mathrm{m})^{1 / 2}\right]$.

Macki and Kochen (21) looked at the stresscorrosion cracking (SCC) behaviors of the U 2.3-wt $\% \mathrm{Nb}$ alloy aged 24 hours at $230^{\circ} \mathrm{C}$ (underaged) and 24 hours at $430^{\circ} \mathrm{C}$ (overaged). The SCC test utilized smooth, dead-weight loaded, static-tensile specimens which were exposed to oxygen-saturated water containing $50 \mathrm{ppm}$ chloride ions. The tests showed that the underaged material was more susceptible to SCC than the overaged material. 


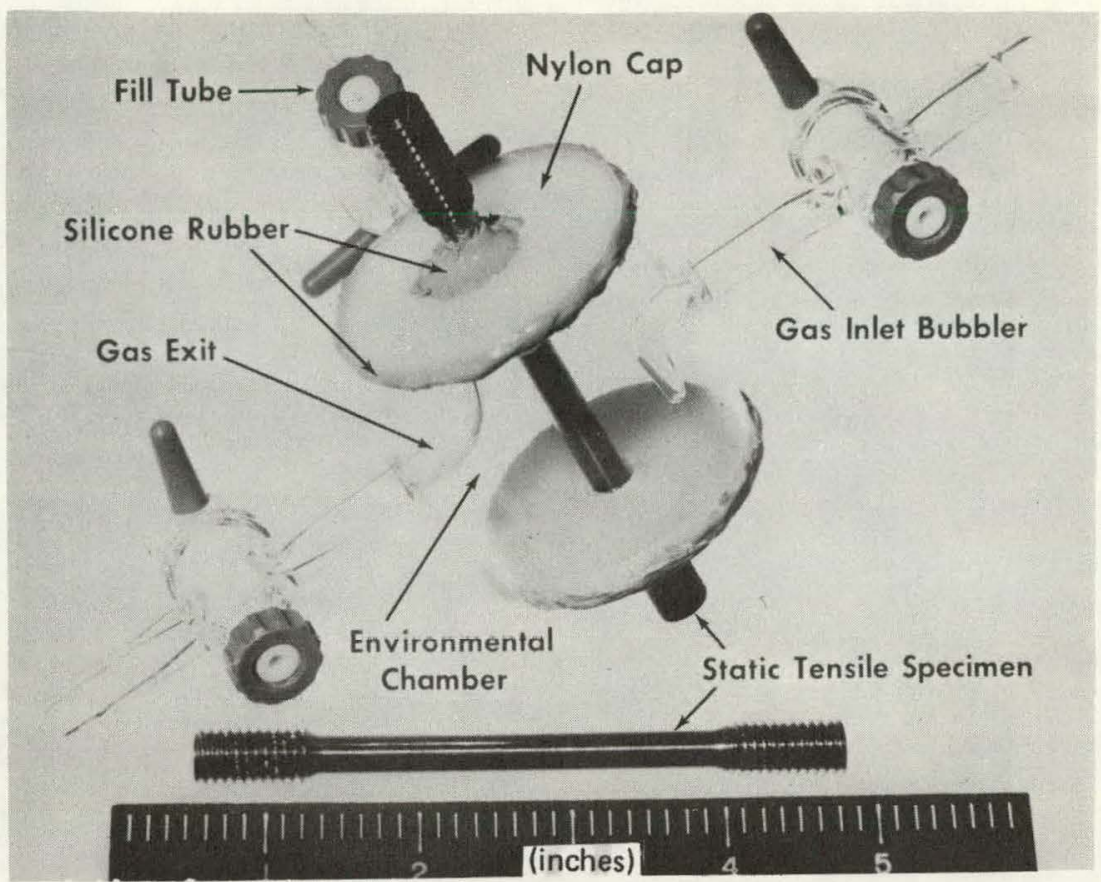

FIGURE 1. Static-tensile, stress-corrosion cracking specimen and environmental chamber.

The SCC in the underaged material proceeded by a transgranular fracture mode. The overaged material did not fracture by an SCC mode; but rather, by a mechanical mode after corrosion had reduced the cross-sectional areas of the specimens.

Magnani and Romero (22) exposed the U 4.5-wt \% $\mathrm{Nb}$ alloy to water-saturated nitrogen and oxygen to determine the rate of reaction of water vapor with the alloys. The data showed that the alloy reacted more slowly than uranium and that oxygen inhibited the reaction. Stress-corrosion tests were also conducted to determine the effects of the environment on the cracking behavior. In moist environments, the data showed that the U 4.5-wt $\% \mathrm{Nb}$ alloy does stress-corrosion crack in either nitrogen or air.

\section{DISCUSSION}

\section{Experimental:}

Smooth, dead-weight loaded, static tensile, stresscorrosion cracking tests were used to compare the susceptibility to stress corrosion cracking of the underaged, overaged, and solution quenched $\mathrm{U}$ 6-wt \% $\mathrm{Nb}$ alloy. The test specimens were round, 4-inch [10.2-centimetres $(\mathrm{cm})]$ long tensile test types with a reduced cross-sectional diameter of 0.253 inches $(0.64 \mathrm{~cm})$. The reduced section was 2.75 inches $(6.98 \mathrm{~cm})$ long connected by a 0.25 inch $(0.64 \mathrm{~cm})$ radius fillet to threaded 0.375 inches $(0.95 \mathrm{~cm})$ diameter ends. A static-tensile test specimen is shown unmounted and also in an environmental test chamber in Figure 1.

The environmental test chamber (Figure 1) was of 1.5-inch $(3.8-\mathrm{cm})$ diameter Pyrex tubing with a gas inlet, gas exit, and fill tube. The end caps were of Nylon and were sealed to the Pyrex and the test specimen with a silicone rubber, Dow Corning 3145 RTV®. This sealant was chosen because of its elasticity and because chloride ions are not leached from it by aqueous solutions.

Each specimen and chamber were mounted on a stressing device which works by means of lead bricks loaded onto the end of a lever beam, as shown in Figure 2. First the test solution, water 


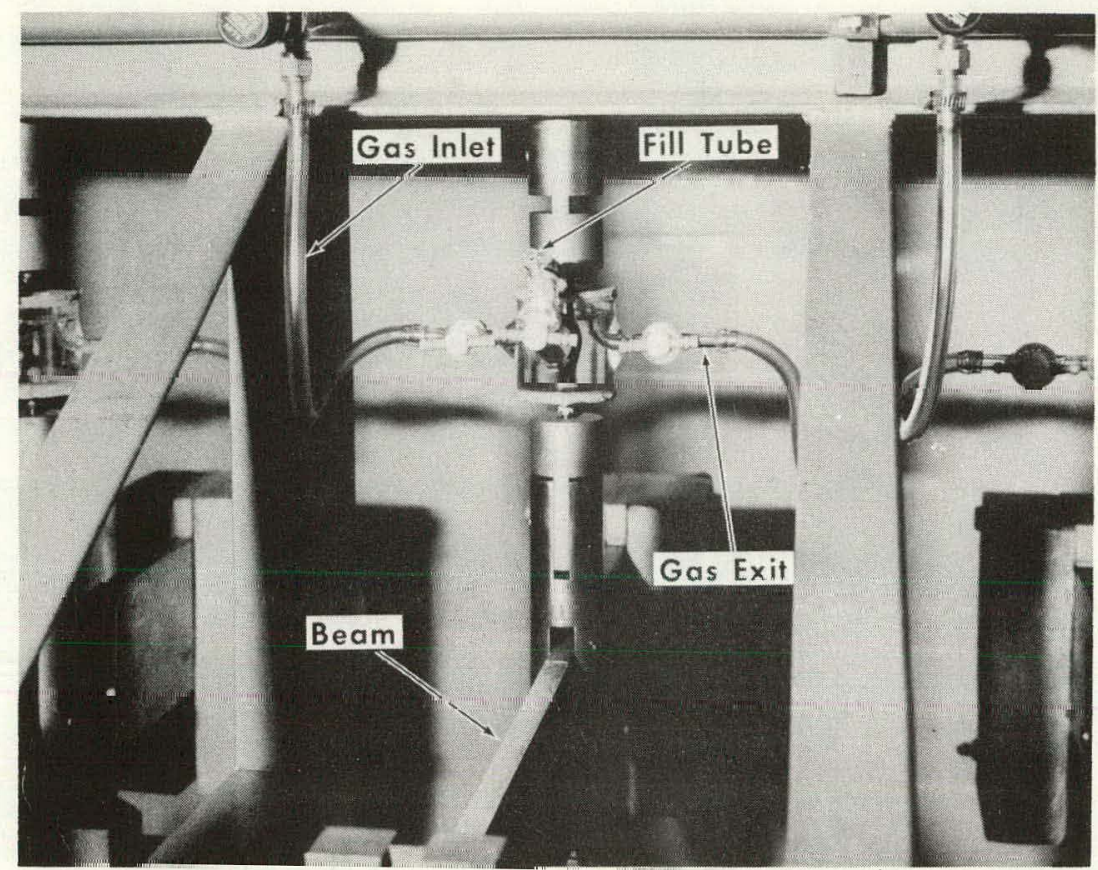

FIGURE 2. Stress-corrosion cracking specimen and environmental chamber mounted in stressing device.

containing a predetermined amount of chloride ions, was introdused into the chamber. Second, nitrogen or oxygen was bubbled through this solution for one hour to achieve saturation. Finally, the load was applied. The dissolved oxygen concentration in the nitrogen-saturated water was not measured.

A 50-ppm chloride ion concentration was achieved by adding reagent grade sodium chloride $(\mathrm{NaCl})$ to distilled water. The chloride-ion concentration was determined by using an Ionalyzer® Model-801 digital $\mathrm{pH}$ meter with a Model-94-17A Ionalyzer chloride-ion electrode and a Model-90-01 Ionalyzer single-junction reference electrode. All of the distilled water plus sodium chloride solutions had initial chloride-ion concentrations of $50 \mathrm{ppm} \pm 1$.

Stress levels for the solution-quenched specimens were $0,11,16,21.5$, and $24 \mathrm{ksi}(0,77,112,150$, and $168 \mathrm{MPa}$, respectively). The underaged and overaged specimens were stressed at $0,48,72,96$, and $108 \mathrm{ksi}(0,336,504,672$, and $756 \mathrm{MPa}$, respectively). In all cases, these stress levels represent 0-, 40-, 60-, 80-, and 90-percent yicld strength of the $\mathrm{U} 6$-wt $\% \mathrm{Nb}$ alloy at room temperature $\left(26^{\circ} \mathrm{C} \pm 2\right)$.

As mentioned earlier, the strength requirements for the underaged and overaged material was a $0.2-$ percent offset yield strength of $120 \mathrm{ksi}$ ( $840 \mathrm{MPa}$ ) with a minimum of 10 percent elongation. These requirements were roughly met by underaging the $\mathrm{U} G$-wt $\% \mathrm{Nb}$ alloy for 6 hours at $250^{\circ} \mathrm{C}$, and by overaging for 80 minutes at $600{ }^{\circ} \mathrm{C}$. The solution-quenched material had a yield strength of $27 \mathrm{ksi}(189 \mathrm{MPa})$ and an elongation of 25 percent. The properties of the underaged, overaged, and solution-quenched material are listed in Table I. After completion of the SCC tests, the Analytical Laboratory examined samples from two each of the underaged, overaged, and solution-quenched SCC specimens. The results are shown in Table II. 
TABLE I. Typical mechanical properties for the solution-quenched, underaged, and overaged uranium 6-weight percent niobium alloy.

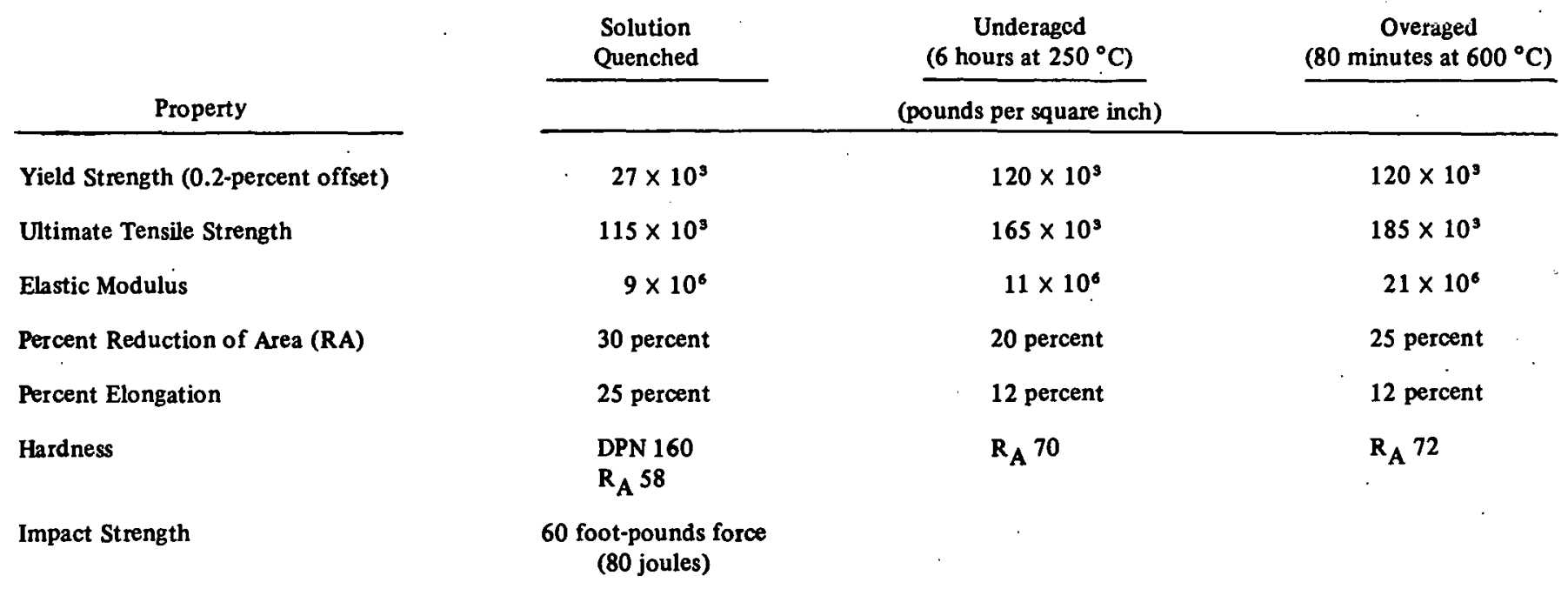

TABLE II. Results of chemical analysis on uranium 6-weight percent niobium specimens (parts per million).

\begin{tabular}{|c|c|c|c|c|c|c|}
\hline Sample & Carbon & Nitrogen & Oxygen & Hydrogen & $\begin{array}{c}\text { Niobium } \\
\text { (weight percent) }\end{array}$ & \\
\hline Underaged & 140 & 120 & 37 & 4.4 & 6.4 & \\
\hline Underaged & 140 & 120 & 42 & 4.4 & 6.1 & \\
\hline Overaged & 140 & 110 & 46 & 4.6 & 6.3 & , \\
\hline Overaged & 140 & 110 & 37 & 5.2 & 6.2 & \\
\hline Solution Quenched & 150 & 110 & 37 & 4.2 & 6.1 & \\
\hline Solution Quenched & 120 & 110 & 33 & 3.8 & 6.1 & \\
\hline
\end{tabular}

\section{Results:}

Smooth, static-tensile SCC tests were used to compare the SCC behaviors of the underaged, overaged, and solution quenched $\mathrm{U} 6$-wt $\% \mathrm{Nb}$ alloy. A smooth specimen SCC test involves stressing the specimen in a test environment and recording the Time-to-Failure (T-F). This T-F is the sum of the crack nucleation time and the crack propagation time.
The results of the static-tensile SCC tests on the U 6-wt \% $\mathrm{Nb}$ alloy are summarized in Tables III and IV. The results for the underaged alloy in $\mathrm{O}_{2}-\mathrm{H}_{2} \mathrm{O}-\mathrm{Cl}^{-}$and $\mathrm{N}_{2}-\mathrm{H}_{2} \mathrm{O}-\mathrm{Cl}^{-}$environments are shown graphically in Figures 3 and 4, respectively; while the results for the overaged alloy in $\mathrm{O}_{2}-\mathrm{H}_{2} \mathrm{O}-\mathrm{Cl}^{-}$and $\mathrm{N}_{2}-\mathrm{H}_{2} \mathrm{O}-\mathrm{Cl}^{-}$environments are shown in Figures 5 and 6, respectively. In Figure 7, a comparison is shown of results for the solutionquenched, underaged, and overaged alloys in the two environments. 
TABLE III. Results of the stress-corrosion cracking tests on uranium 6-weight percent niobium.

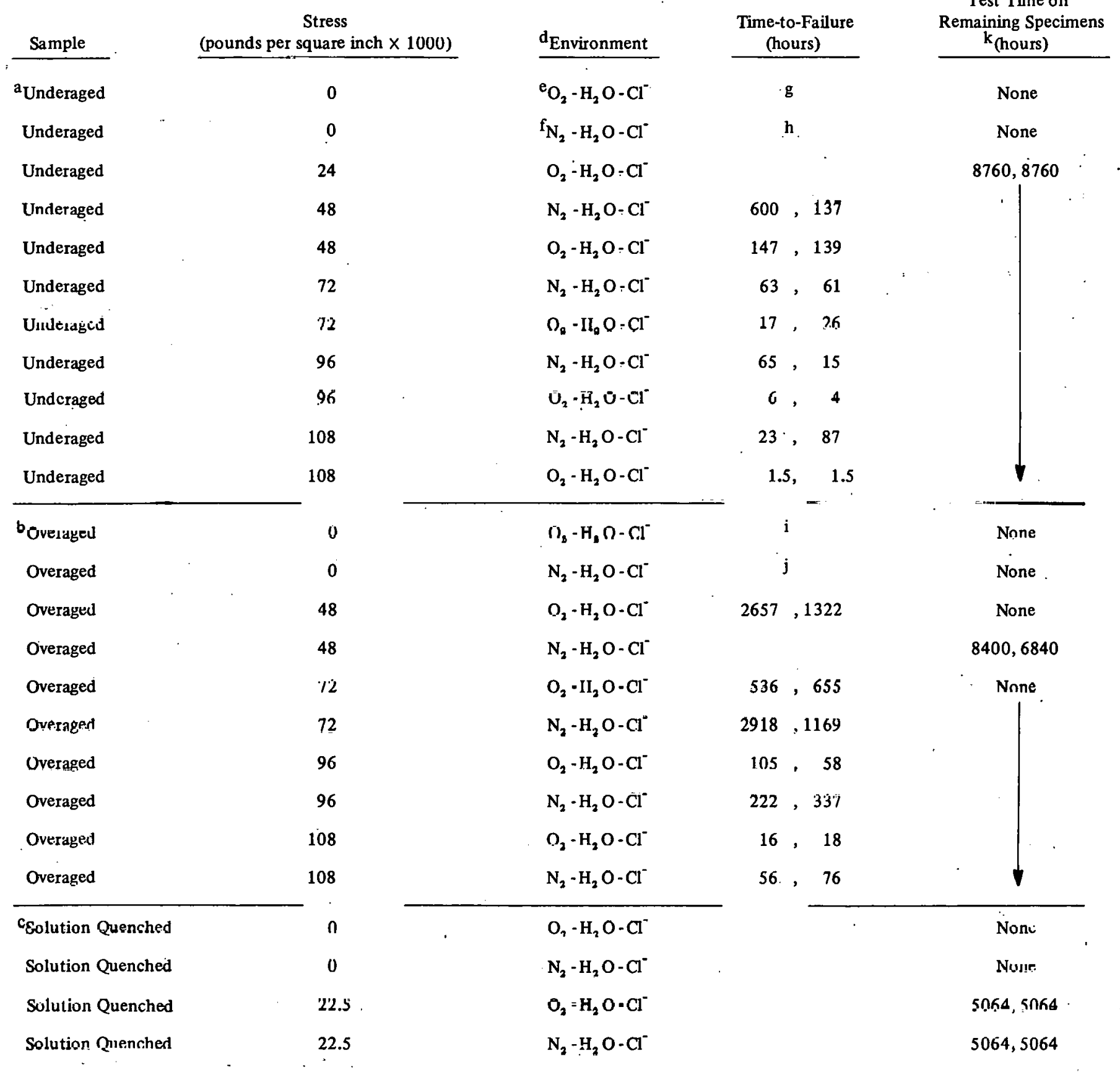

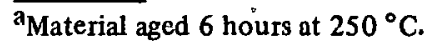

b Material aged 80 minutes at $600^{\circ} \mathrm{C}$.

${ }^{\mathrm{c}}$ Solution quenched condition (the soft condition).

d All test temperatures were $26^{\circ} \mathrm{C} \pm 2$.

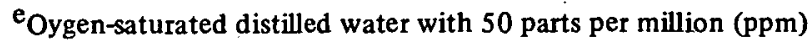
chloride ions.

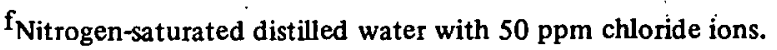

goth samples removed from environment after 1.5-hours; tensile tests indicated ultimate strengths of 144 and 149 thousand pounds per square inch (see Table IV).

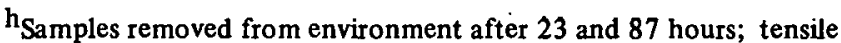
tests indicated ultimate strengths of 139 and 151 thousand pounds per square inch, respectively (see Table IV).

${ }^{i}$ Samples removed from environment after 16 and 18 hours; tensile tests indicaled ultumate strengths of 158 und 158 livisiand pounds per square inch, respectively (see Table IV).

jSamples removed from environment after 56 and 76 hours; tensile tcsts indicated ultimate strengths of 172 and 167 thousand pounds per square inch, respectively (see Table IV).

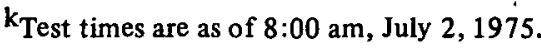


RFP-2429

TABLE IV. Characteristics of the underaged and overaged stresscorrosion cracking tests on uranium 6-weight percent niobium.

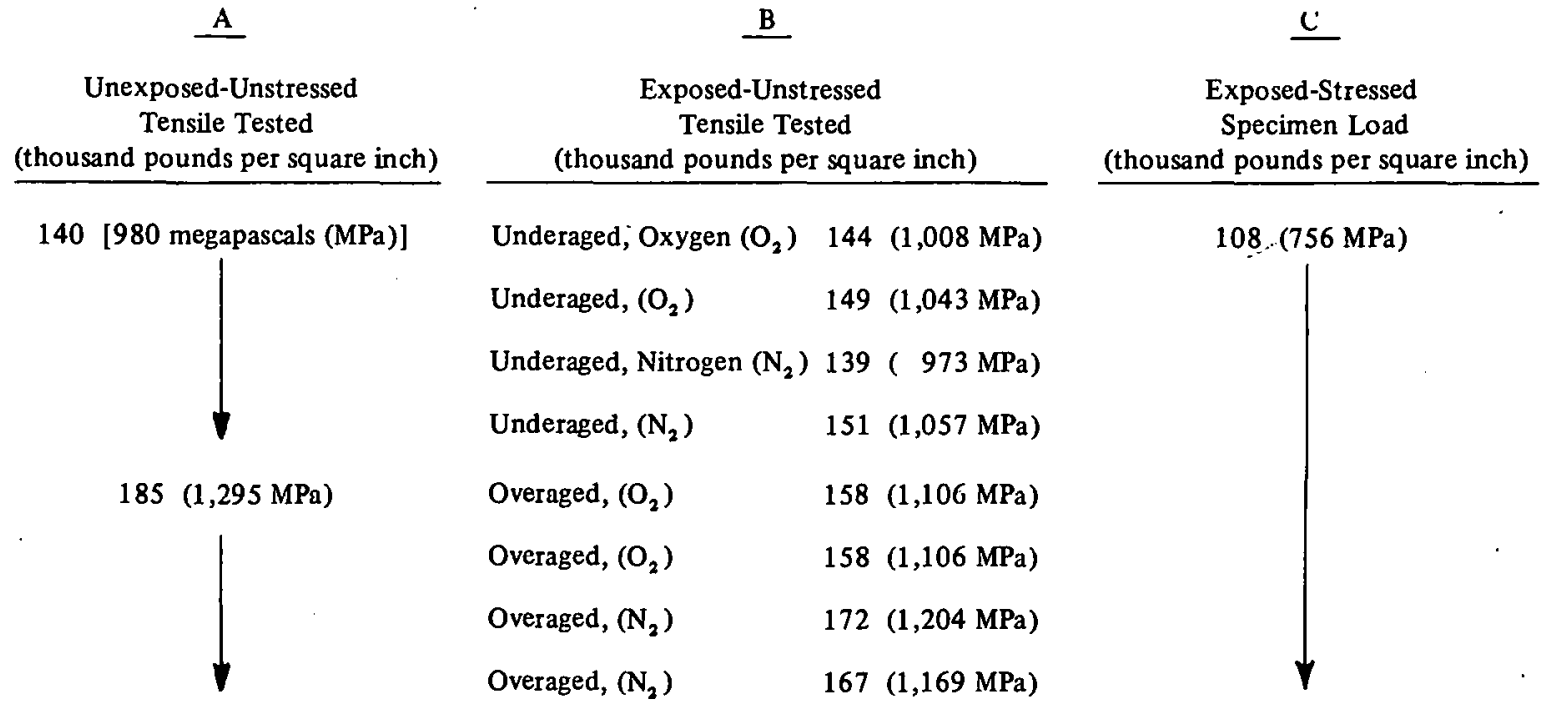

The U 6-wt $\% \mathrm{Nb}$ alloy in the gamma-quenched condition did not show any susceptibility to stress-corrosion cracking when loaded to 90 percent of yield strength in either the oxygen-saturated or nitrogen-saturated aqueous solutions containing $50 \mathrm{ppm} \mathrm{Cl}^{-}$. The gamma-quenched material (water quenched after one hour at $850^{\circ} \mathrm{C}$ ) had a 0.2 percent offset yield strength of about $27,000 \mathrm{psi}$ (189 MPa) and an ultimate strength of $115,000 \mathrm{psi}$, $(805 \mathrm{MPa})$ and was stressed to 90 percent of yield, i.e., 24,000 psi (168 MPa). Failure did not occur in 5,064 hours (211 days) of testing in either of the hostile environments. Thus, one can conclude that the gamma-quenched material is not susceptible to stress-corrosion cracking in the two chloride-ion solutions tested.

The underaged alloy in oxygen-saturated water containing $50 \mathrm{ppm}$ chloride ions showed failures when stressed at $90,80,60$, and 40 percent of yield strength, but not when stressed at 20 percent of yield. The stress required for failure was linear with respect to a log-time scale (Figure 3 ), and at zero time was approximately the ultimate tensile - strength of the alloy. A threshold stress may exist between 24,000 and 48,000 psi (168 and $336 \mathrm{MPa}$ ), since no failures were observed after 8,760 hours (365 days) of testing at 20 percent of yield strength.

The underaged alloy in nitrogen-saturated water containing $50 \mathrm{ppm} \mathrm{Cl}^{-}$also showed failures when tested at $90,80,60$, and 40 percent of yield strength. However, the time-to-failure varied appreciably (Figure 4) and may indicate that oxygen is required for stress-corrosion cracking in the nitrogen-saturated aqueous solutions containing $50 \mathrm{ppm} \mathrm{Cl}^{-}$. The time-to-failure would then include the time required for the necessary oxygen to get into the environmental chamber. None-the-less, one can conclude that the underaged material stress-corrosion cracks in both environments and that the susceptibility is greater in oxygen-saturated rather than nitrogensaturated aqueous chloride solutions (Figure 7).

The underaged alloys $\left(6\right.$ hours at $250^{\circ} \mathrm{C}$ ) showed a mixed transgranular and intergranular fracture mode in both environments with the transgranular mode predominating. Figures $8(a)$ and (b) show transverse views of the fracture zone of a sample tested at 80 percent of yield strength in the oxygen-saturated aqueous chloride solution. 
FIGURE 3. Stress-corrosion cracking behavior of underaged (6 hours at $250{ }^{\circ} \mathrm{C}$ ) uranium 6 weight percent niobium in oxygen-saturated water containing 50 parts per million chloride ions.

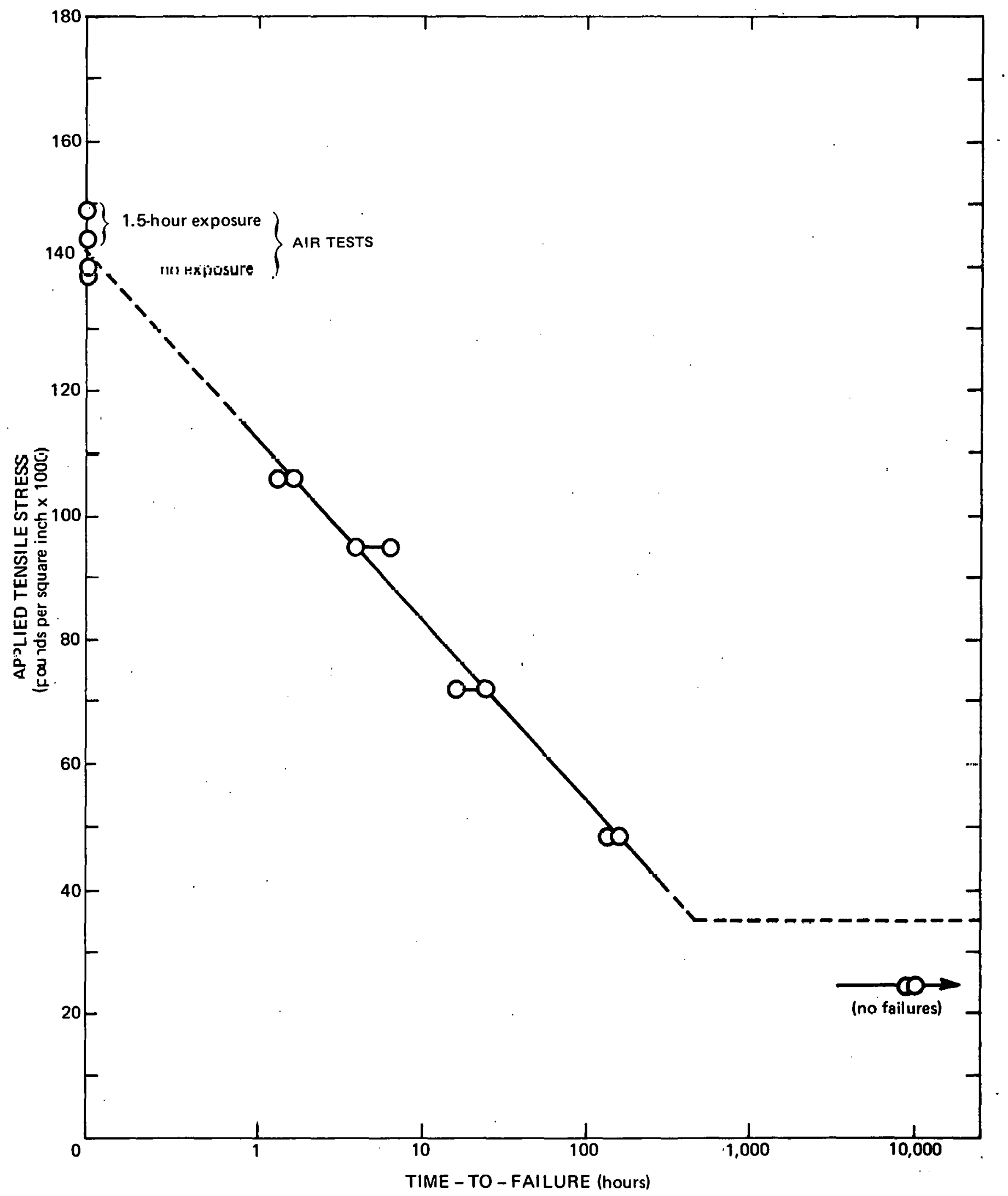


FIGURE 4. Stress-corrosion cracking behavior of underaged ( 6 hours at $250^{\circ} \mathrm{C}$ ) uranium 6 . weight percent niobium in nitrogen-saturated water containing 50 parts per million chloride ions.

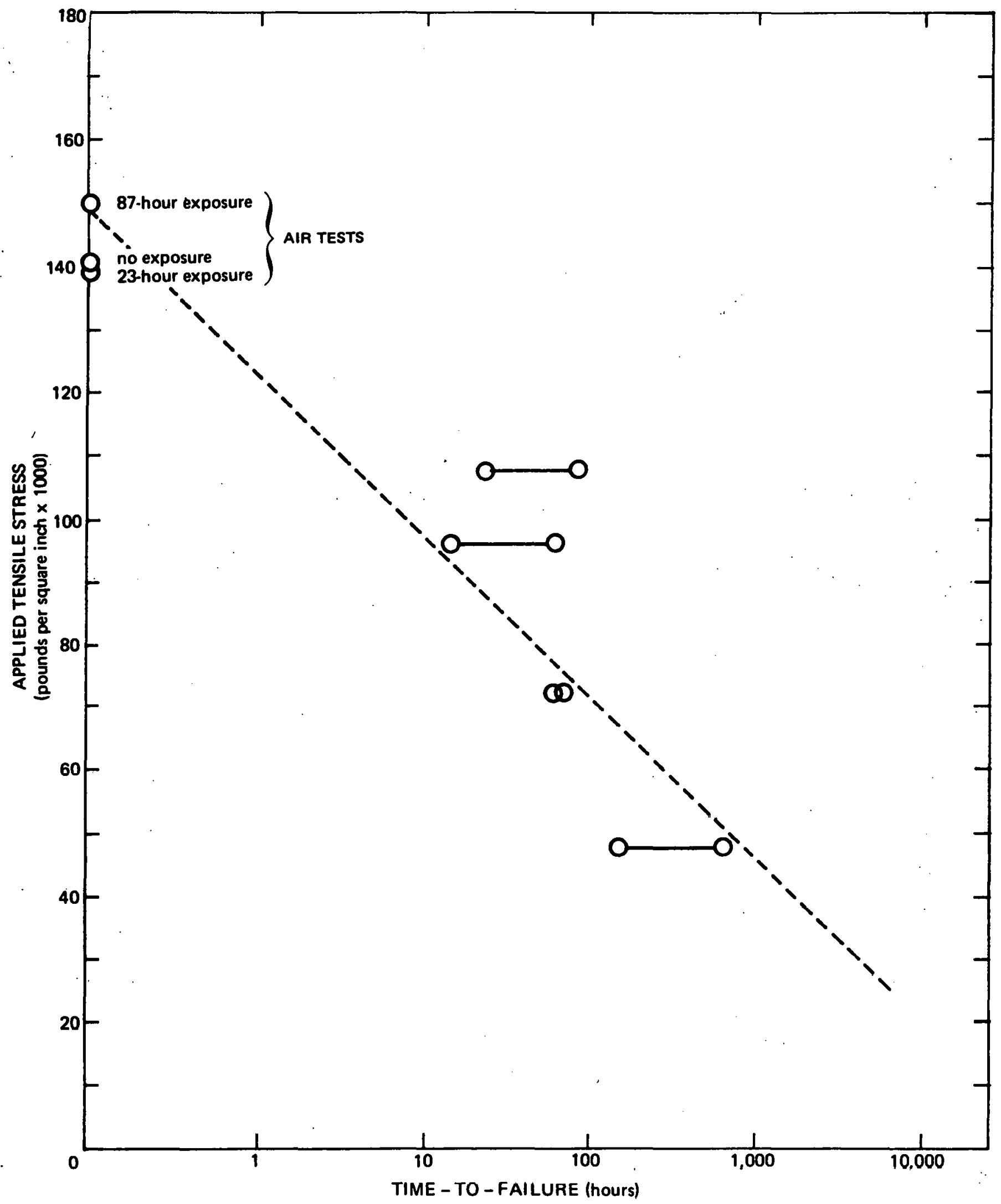


FIGURE 5. Stress-corrosion cracking behavior of overaged ( 80 minutes at $600{ }^{\circ} \mathrm{C}$ ) uranium 6 weight percent niobium in oxygen-saturated water containing 50 parts per million chloride ions.

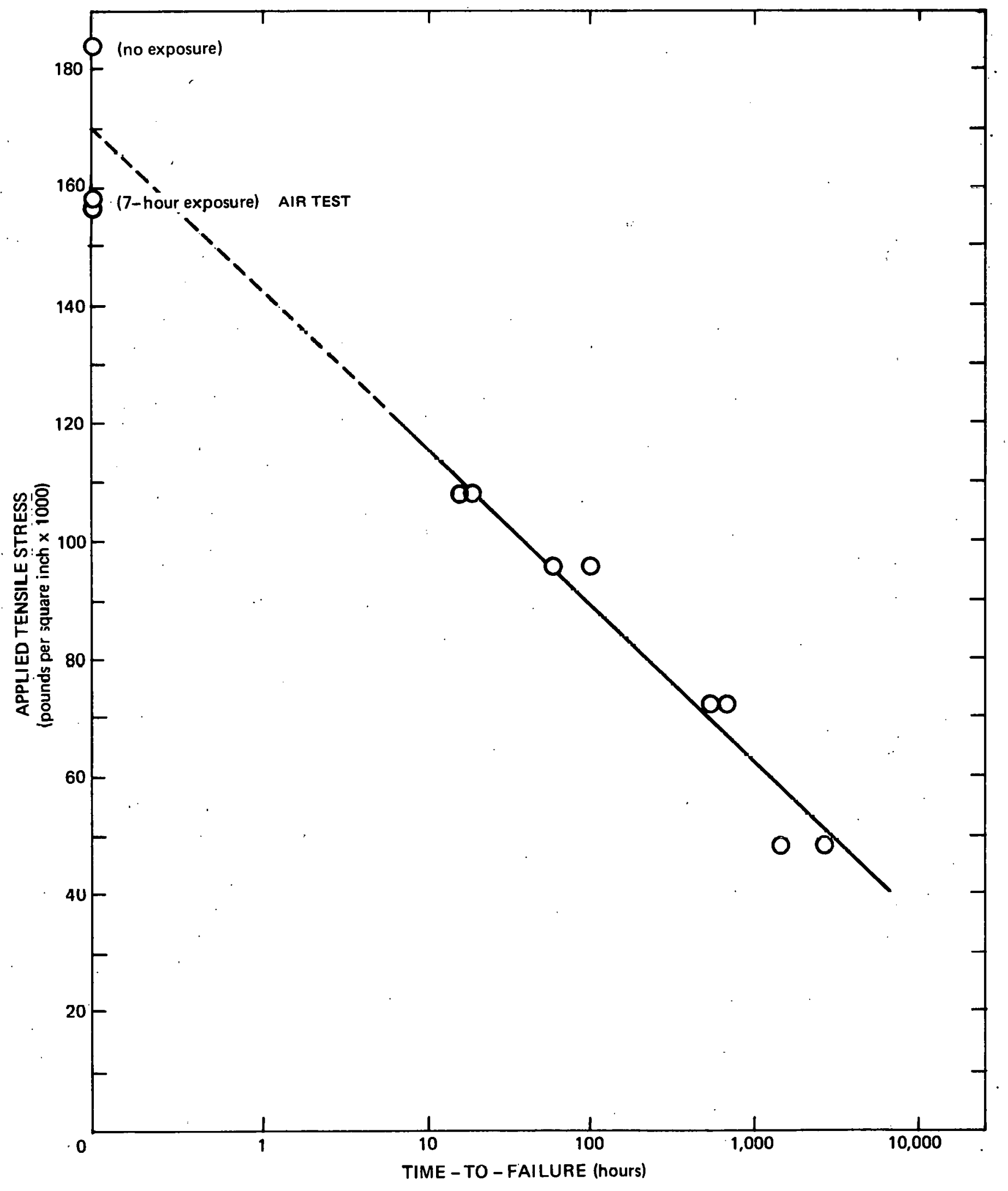


FIGURE 6. Stress-corrosion cracking behavior of overaged $\left(80\right.$ minutes at $600{ }^{\circ} \mathrm{C}$ ) uranium 6weight percent niobium in nitrogen-saturated water containing 50 parts per million chloride ions.

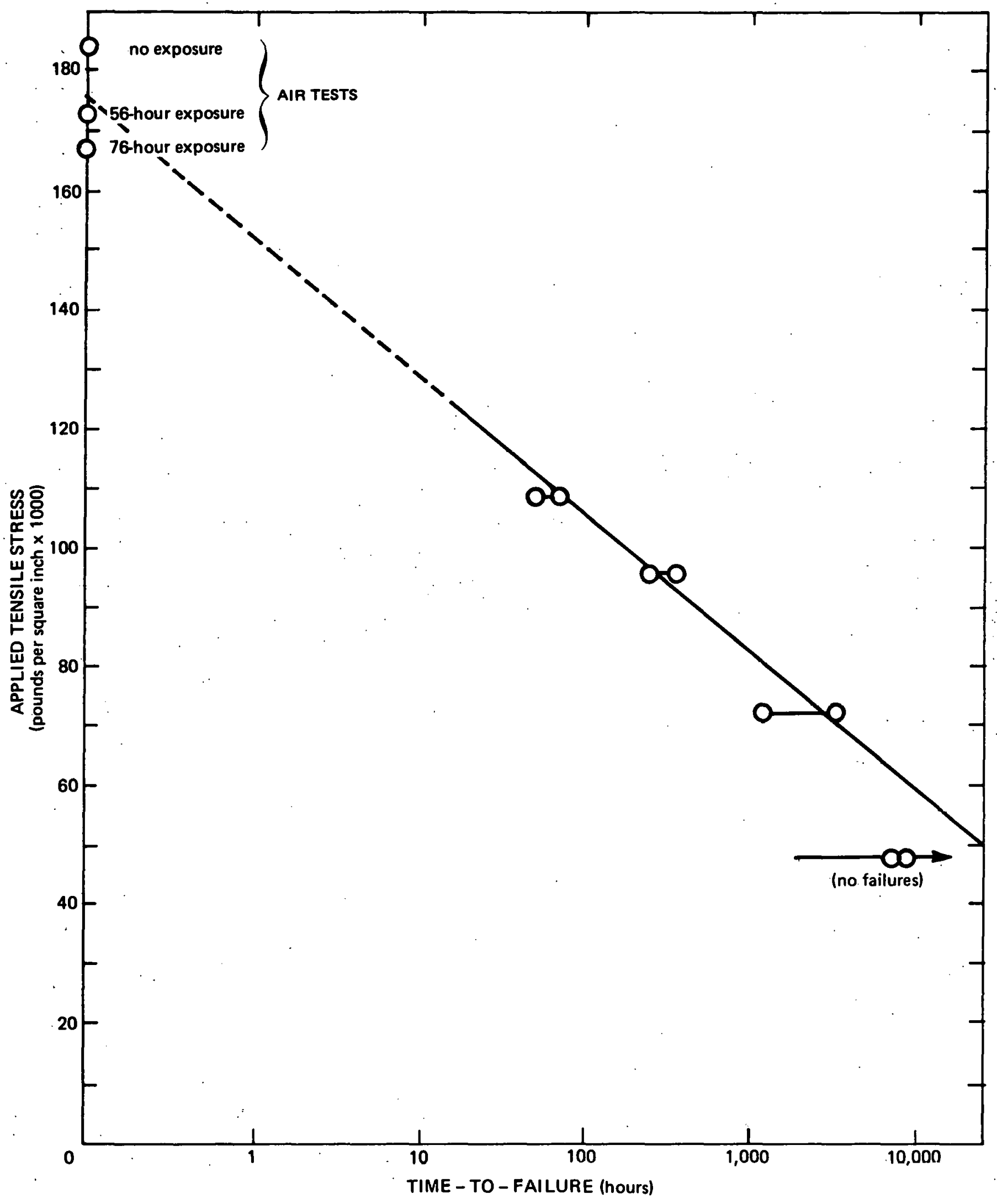


FIGURE 7. Comparative stress-corrosion cracking behavior of the solutionquenched, underaged, and overaged uranium 6-weight percent niobium alloy in oxygen and nitrogen saturated water containing 50 parts per million chloride ions.

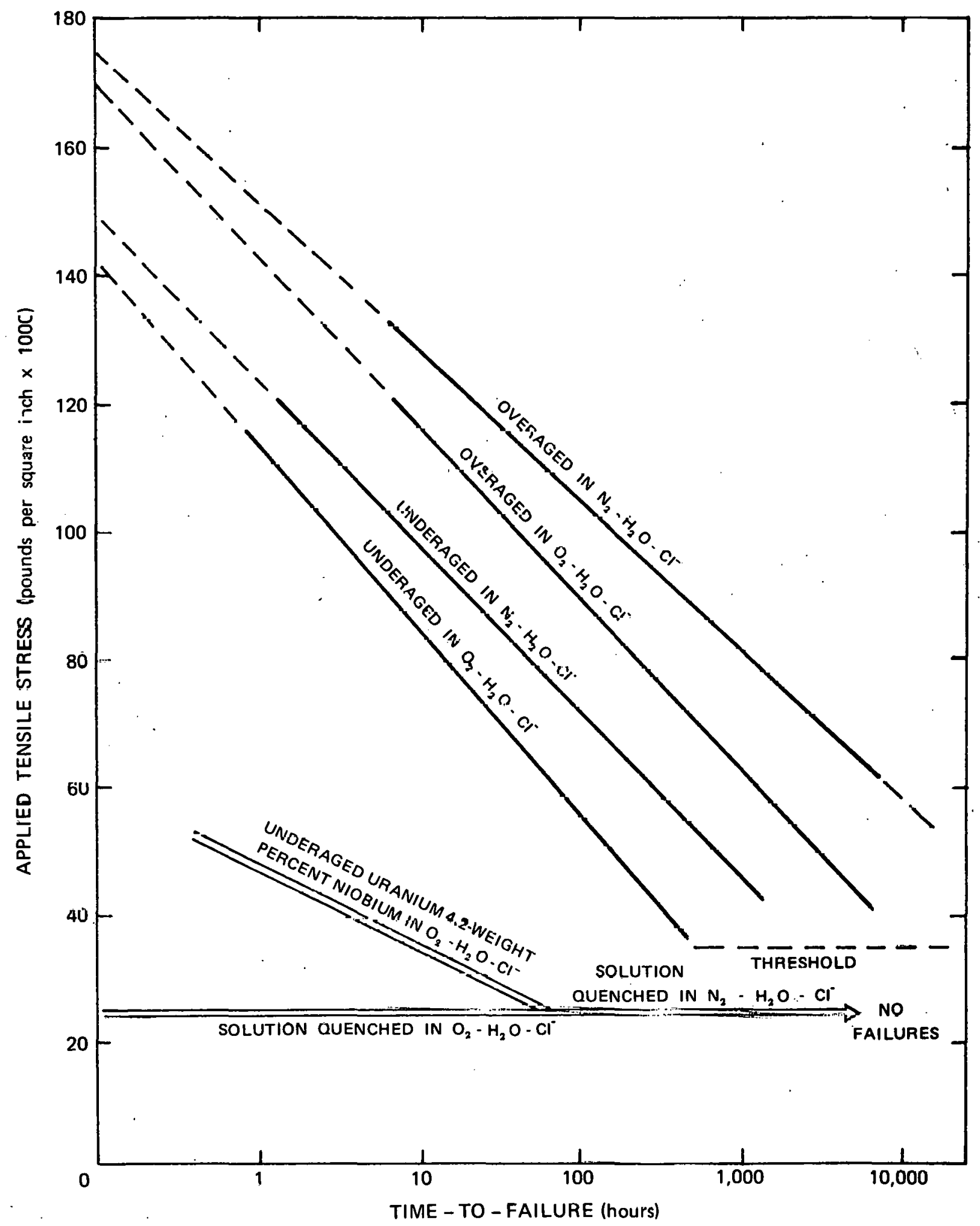



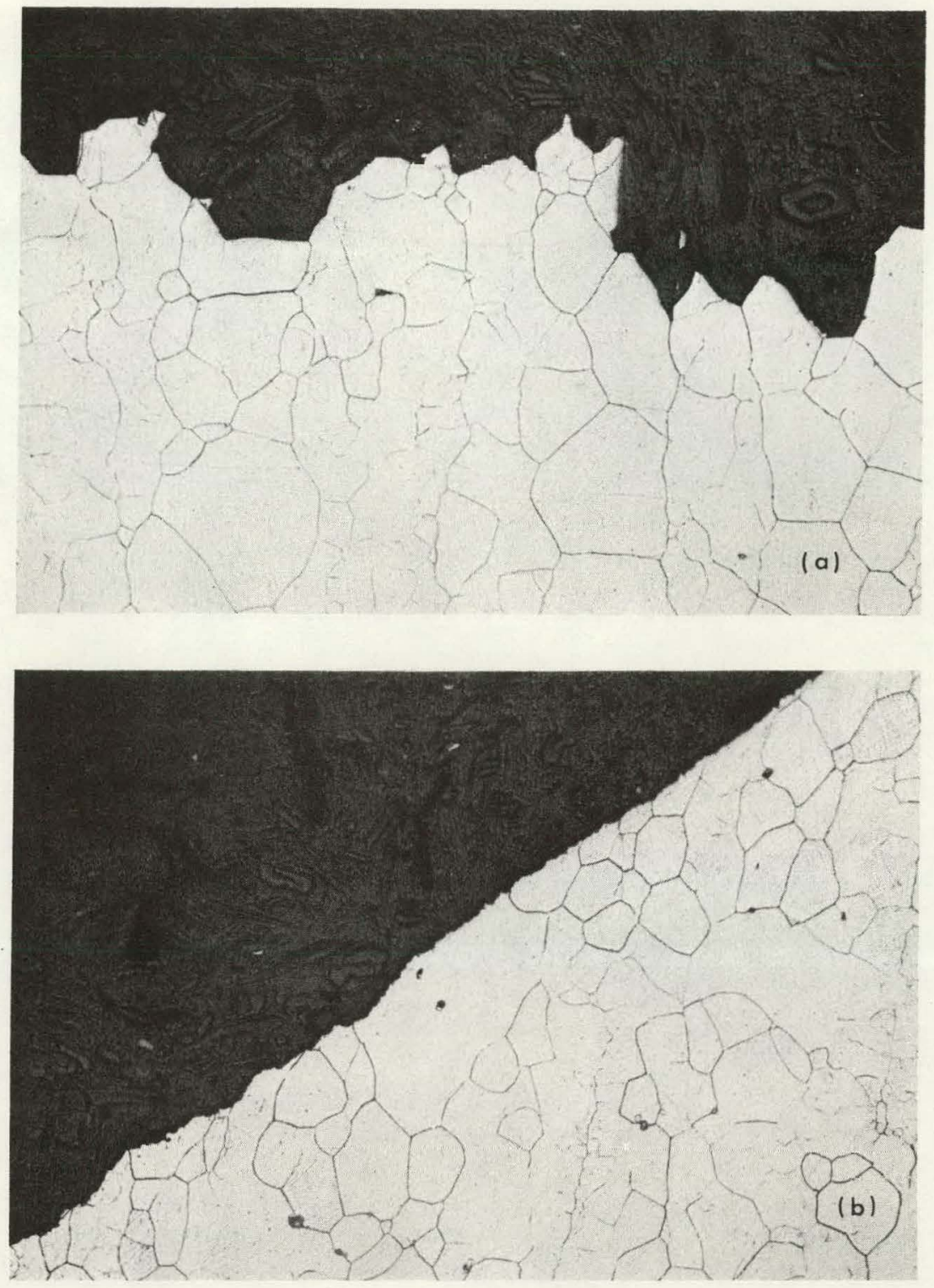

FIGURES 8(a) and (b). Transverse views of fracture zone of underaged uranium 6-weight percent niobium alloy tested at 80 percent of yield strength in oxygensaturated water containing 50 parts per million chloride ions. Magnification 200X.

Figures 9(a) and (b) show transverse views after testing at 90 percent of yield in the nitrogensaturated aqueous chloride solution. The fracture mode for underaged samples tested in air was transgranular. Hence, the two test environments do promote intergranular cracking.

The overaged alloy ( 80 minutes at $600^{\circ} \mathrm{C}$ ) in oxygen-saturated aqueous chloride solution showed failures when tested at $90,80,60$, and 40 percent of yield strength (120 ksi or $840 \mathrm{MPa})$. As with the underaged alloy, the stress required for failure was linear with respect to a log-time scale (Figure 5), and when extrapolated to zero time was approximately the ultimate tensile strength of the alloy. The time required for failure was significantly longer than that of the underaged material under similar conditions of stress and 

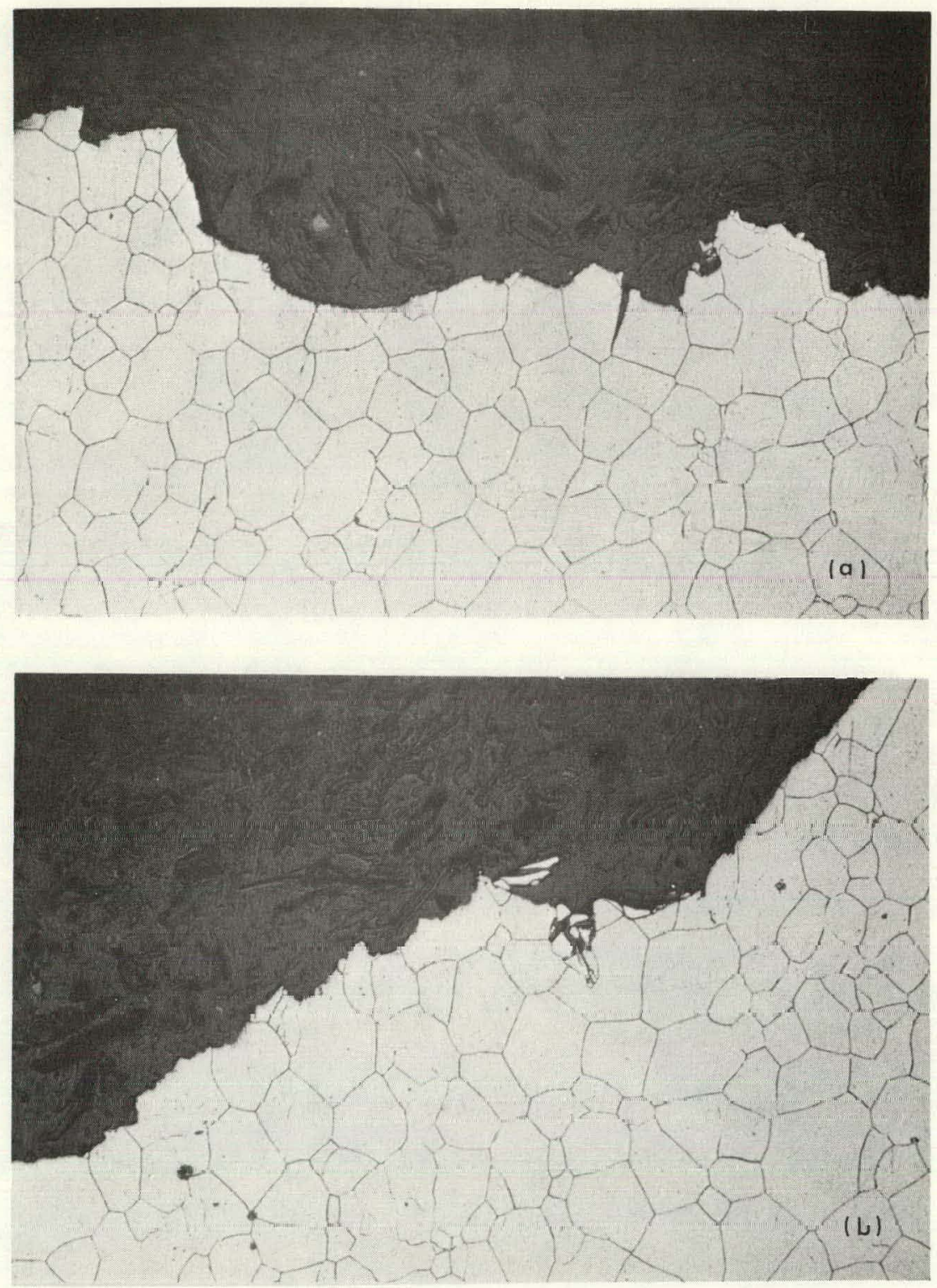

TICIIRTS $9($ a) and (h). Transverse vicws of fracture zone of underaged uranium 6-weight percent niobium alloy tested at 90 percent of yield strength in nitrogen-saturated water containing 50 parts per million chloride ions.

environment. Thus, one can conclude that the overaged alloy is less susceptible to stress-corrosion cracking than is the underaged alloy. However, this may be due to a higher ultimate tensile strength in the overaged material, even though both had approximately the same 0.2 -percent offset yield strengths.
The overaged alloy in nitrogen-saturated water containing $50 \mathrm{ppm} \mathrm{Cl}^{-}$also showed failures when tested at 90,80 , and 60 percent of yield strength, but not when tested at 40 percent of yield strength (Figure 6). This, however, does not indicate a threshold value, but merely that the samples were not stressed long enough for failure to occur. 
An extrapolation of the fracture data would indicate a life of about 20,000 hours ( 833 days), and the sampes were only tested for 8,400 hours (350 days). The overaged alloy in the $\mathrm{N}_{2}-\mathrm{H}_{2} \mathrm{O}-\mathrm{Cl}^{-}$ solution had the longest time-to-failure of the four overaged and underaged alloys tested. Here again, this may be due to the higher ultimate tensile strength of the overaged material and the necessity for oxygen leakage into the $\mathrm{N}_{2}-\mathrm{H}_{2} \mathrm{O}-\mathrm{Cl}^{-}$solution in the environmental chamber.

In view of the earlier statement, the question arises as to why samples were not tested in oxygensaturated distilled water without chloride ions, i.e., oxygen may be a more important ingredient than chloride ions. The reason related to an earlier effort which showed (19) that SCC specimens of the $\mathrm{U} 4.2-\mathrm{wt} \% \mathrm{Nb}$ alloy had extremely long lives in oxygen-saturated distilled water, and that chloride ions were required for, or at least accelerated, the nucleation or propagation (or both) of SCC cracks. For comparison, the time-to-failure of the U 4.2-wt $\% \mathrm{Nb}$ underaged $\left(80\right.$ hours at $260^{\circ} \mathrm{C}$ ) alloy in oxygen-saturated distilled water containing $50 \mathrm{ppm}$ chloride ion is shown in Figure 7. Thus, the U 6-wt $\% \mathrm{Nb}$ alloy is much less susceptible to stress corrosion cracking in $\mathrm{O}_{2}-\mathrm{H}_{2} \mathrm{O}-\mathrm{Cl}^{-}$solutions than is the $\mathrm{U} 4.2-\mathrm{wt} \% \mathrm{Nb}$ alloy.

It has been stated, especially with constant load tests, that the stress-corrosion of an alloy with unknown susceptibility can be established by exposing both stressed and unstressed specimens to the same corrosive environment (23). For instance, three tension specimens, A, B, and C, are used as examples. Specimen A is an unexposed, unstressed blank; Specimen B is exposed to a corrosive environment, but in an unstressed condition. Specimen $\mathrm{C}$ is both stressed and exposed to the same corrosive environment. When Specimen C breaks, under the combined influence of stress and corrosion, Specimen B is tension-tested. If Specimen B has a breaking load closer to that of Specimen A, the evidence is greater that Specimen $\mathrm{C}$ failed at a result of stress-corrosion cracking. This appears to be the case with the underaged material as shown in Table IV and in Figures 3 and 4.

If, however, the breaking load of Specimen B is closer to the load on Specimen C, then the failure of Specimen C should not be attributed to stresscorrosion cracking, but rather to the probability that the specimen corroded to the point where it could no longer support the load. The breaking load of the overaged B specimens (exposed but unstressed) is somewhat closer to the overaged A specimens (unexposed and unstressed). None-theless, the overaged B specimens had a reduced breaking load when compared to the overaged $\mathrm{A}$ specimens (Table IV and Figures 5 and 6), and do indicate that corrosion reduced the effective crosssectional area of these specimens resulting in an overload condition and a partial mechanical failure. Also, visual examination showed that corrosion effectively reduced the cross-sectional area of these specimens. Therefore, the overaged material partially fails by corrosion reducing the crosssectional area rather than totally by an SCC fracture mode.

The structure of the overaged material ( 80 minutes at $600{ }^{\circ} \mathrm{C}$ ) is fine pearlite consisting of orthorhombic alpha and body-centered-cubic gamma phase. Optical micrographs did not clearly resolve the fine pearlite, but prior gamma grain boundaries are discernible (Figure 10). Replicas of the surface in an electron microscope did resolve the fine pearlite (Figure 11). Due to the nature of the microstructure, the fracture mode would have to be, at least, partially transcrystalline. However because of the fineness of the structure, this was not actually observed. A macroscopic view of the fracture is shown in Figure 12. The smooth area near the initiation of the overload fracture is probably a stress-corrosion crack which acted as a stress raiser causing the overload fracture.

\section{CONCLUSIONS}

1. The U 6-wt \% $\mathrm{Nb}$ alloy in the solutionquenched condition does not appear to be susceptible to stress-corrosion cracking when loaded to 90 percent of yield strength in oxygen or nitrogen saturated solutions containing $50 \mathrm{ppm}$ chloride ions.

2. The U 6-wt $\% \mathrm{Nb}$ alloy in the underaged condition ( 6 hours at $250^{\circ} \mathrm{C}$ ) is susceptible 


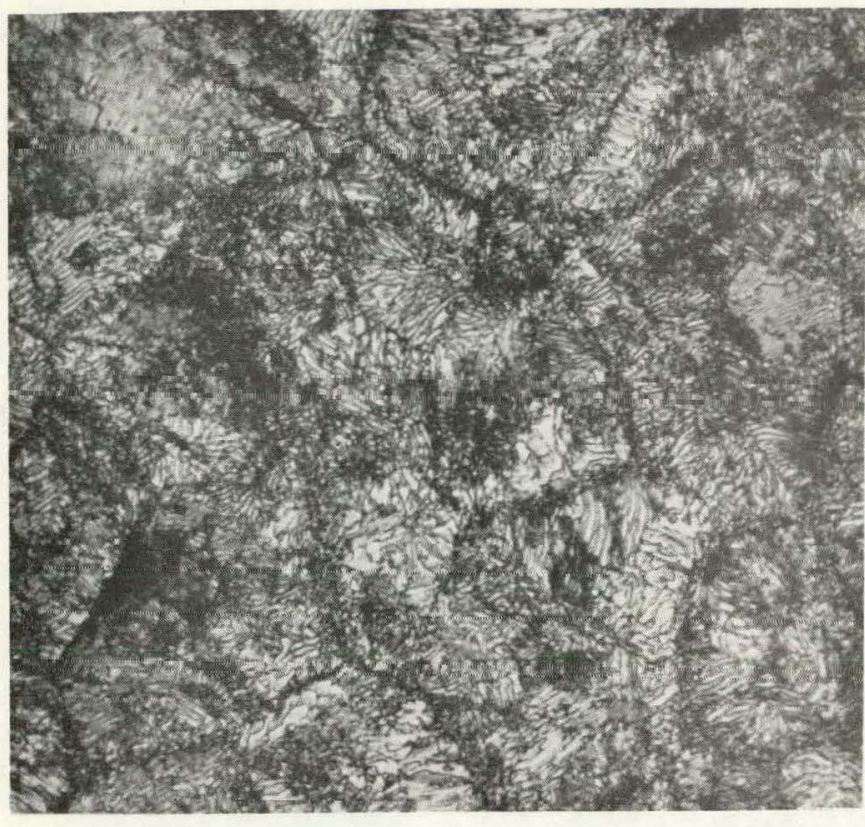

FIGURE 10. Optical photomicrograph of uranium 6weight percent niobium alloy aged 80 minutes at $600{ }^{\circ} \mathrm{C}$ showing partially resolved pearlitic structure within prior gamma grain boundaries. Magnification 1000X.

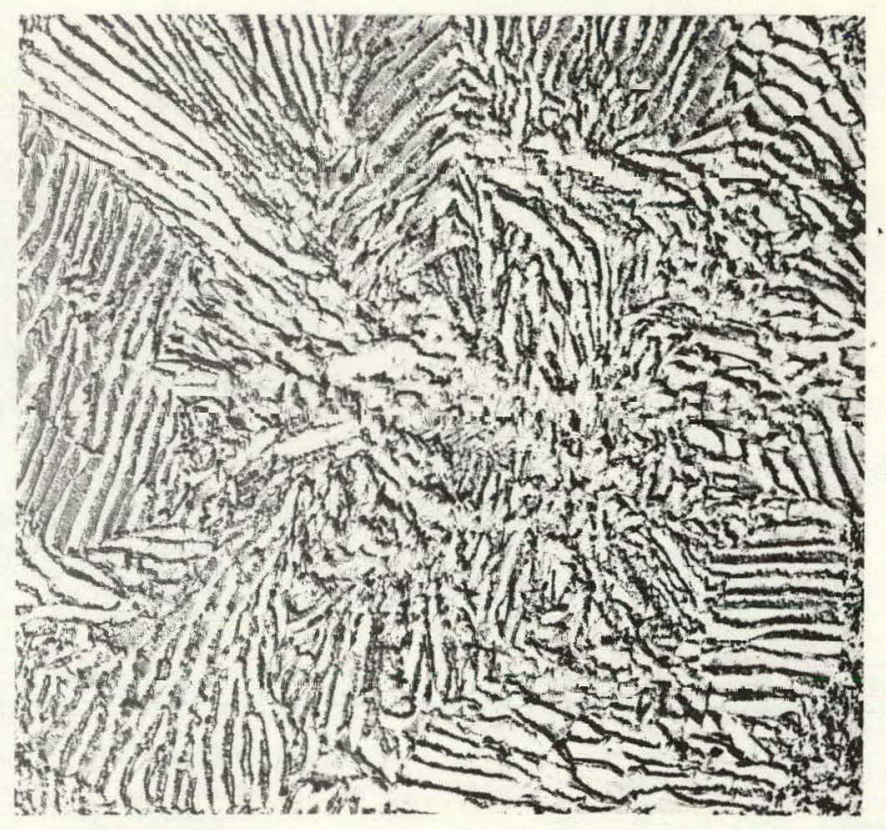

FIGURE 11. Electron miciograph of replicated surface of sample in Figure 10 showing resolved pearlitic structure. Magnification 5000X.

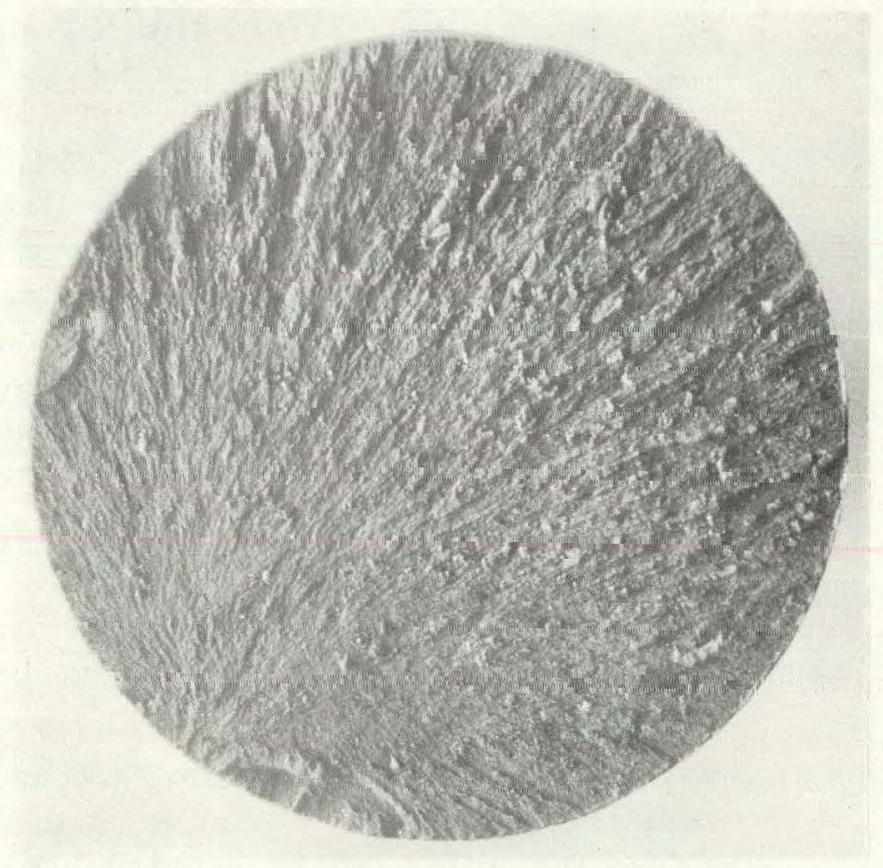

FIGURE 12. Macroscopic view of fracture surface of overaged uranium 6-weight percent niobium alloy tested at 60 percent of yield strength in nitrogen-saturated water containing 50 parts per million chloride ions. Magnification $12 \mathrm{X}$. 
to stress-corrosion cracking in oxygensaturated solutions containing $50 \mathrm{ppm}$ chloride ions when loaded at $90,80,60$, and 40 percent of yield strength, but not when loaded at 20 percent of yield indicating a threshold value.

3. The underaged alloy is also susceptible to SCC in nitrogen-saturated aqueous chloride solutions when loaded at $90,80,60$, and 40 percent of yield strength.

4. The $\mathrm{U}$ 6-wt $\% \mathrm{Nb}$ alloy in the overaged conditions $\left(80\right.$ minutes at $600{ }^{\circ} \mathrm{C}$ ) also fails when loaded to $90,80,60$, and 40 percent of yield strength in either oxygen or nitrogen saturated aqueous solutions containing $50 \mathrm{ppm}$ chloride ions. Both a mechanical cracking mode and a stress-corrosion cracking mode appear to be operable, i.e., stress-corrosion cracks form at the same time corrosion is reducing the crosssectional area of the material.

5. The order of susceptibility to stress-corrosion cracking of the $\mathrm{U}$ 6-wt \% $\mathrm{Nb}$ alloy is:

a. Most susceptible - Underaged alloy in $\mathrm{O}_{2}-\mathrm{H}_{2} \mathrm{O}-\mathrm{Cl}^{-}$ environment.

b. Most susceptible - Underaged alloy in $\mathrm{N}_{2}-\mathrm{H}_{2} \mathrm{O}-\mathrm{Cl}^{-}$ environment.

c. Most susceptible - Overaged alloy in $\mathrm{O}_{2}-\mathrm{H}_{2} \mathrm{O}-\mathrm{Cl}^{-}$ environment.

d. Most susceptible - Overaged alloy in $\mathrm{N}_{2}-\mathrm{H}_{2} \mathrm{O}-\mathrm{Cl}^{-}$ environment.

e. Least susceptible - Solution-quenched alloy in either the $\mathrm{O}_{2}-\mathrm{H}_{2} \mathrm{O}-\mathrm{Cl}^{-}$or $\mathrm{N}_{2}-\mathrm{H}_{2} \mathrm{O}-\mathrm{Cl}^{-}$ environments.

\section{REFERENCES}

1. B. A. Rogers et al. "Uranium-Columbium Alloy Diagram Transactions." Transactions Metallurgical Society, American Institute of Mining and Metallurgical Engineers 212:387. 1975.

2. P. C. Pfeil et al. "Uranium-Niobium Alloy System in the Solid State." Journal of the Institute of Metals 87:204. 1959.

3. M. Anagnostidis et al. "Phases Metastables Dans Les Alliages Uranium-Niobium." Journal of Nuclear Materials 11:67. 1964.

4. K. Tangri and D. K. Chaudhuri. "Metastable Phases in Uranium Alloys with High Solute Solubility in the BCC Gamma Phase." Part I The System U-Nb. Journal of Nuclear Materials 15:278. 1964.

5. C. D'Amato et al. "Phase Transformations and Equilibrium Structures in Uranium-Rich Niobium Alloys." Journal of Nuclear Materials 12:291. 1964.

6. R. J. Jackson. Reversible Martensitic Transformations between Transition Phases. USAEC RFP-1535. Rocky Flats Division, The Dow Chemical Company, Golden, Colorado. December 23, 1970.

7. R. J. Jackson and D. V. Miley. "Tensile Properties of Gamma-Quenched and Aged Uranium-Base Niobium Alloys." American Society for Metals Transactions Quarterly $61: 336$ : 1968.

8. J. T. Waber. "Corrosion Behavior of Plutonium and Uranium." Page 204. Proceedings of the Second United Nations International Conference on Peaceful Uses of Atomic Energy. Volume 6. United Nations Publication, Geneva, Switzerland. 1958.

9. J. M. Macki and R. L. Kochen. Corrosion Behavior of Uranium Alloys in Hydrochloric 
Acid and Ocean Water. USAEC RFP-1586. Rocky Flats Division, The Dow Chemical Company, Golden, Colorado. February 26, 1971.

10. J. M. Macki and R. L. Kochen. Galvanic Corrosion Behavior of Uranium Alloys in Hydrochloric Acid and Ocean Water. USAEC RFP-1592. Rocky Flats Division, The Dow Chemical Company, Golden, Colorado. February 24, 1971.

11. W. E. Tragert. "Factors Influencing Stress Corrosion of Reactor Materials." Corrosion et anticnrrosion 8:196-201. May 1960. (In French). [A translation of this report by R. G. Mansfield is USAEC Report ORNL-tr2154.]

12. S. Orman. "Rapid Test for Stress-Corrosion Cracking." Corrosion Science 9:849. November 1969.

13. L. L. Stephenson. Survey of Factors which Influence Stress-Corrosion Crack Initiation in Several Uranium Base Alloys. USAEC Report SC-DR-70-718. Sandia Corporation, Albuquerque, New Mexico. October 1970.

14. N. J. Magnani, H. Romero, and C. J. Miglionico. Effect of Chloride Ions on the Susceptibility to Stress Corrosion Cracking of U-7.5 Wt Percent $\mathrm{Nb}-2.5 \mathrm{Wt}$ Percent $\mathrm{Zr}$ and $\mathrm{U}-4.5 \mathrm{Wt}$ Percent $\mathrm{Nb}$ Alloys. USAEC Report SC-RR-70-860. Sandia Corporation, Albuquerque, New Mexico. December 1970.

15. N. J. Magnani, H. Romero, and C. J. Miglionico. Stress Corrosion Cracking Behavior of Tungsten Filament Reinforced U-4.5 Wt Percent $N b$. USAEC Report SC-DR-7 10799. Sandia Corporation, Albuquerque, New Mexico. November 1971.

16. B. D. McLaughlin, L. L. Stephenson, and C. J. Miglionico. "Influence of Aging Time and Temperature on the Susceptibility of
$\lambda$-Quenched U-5 Wt Percent Nb Alloy to SCC." Corrosion 28:35. January 1972.

17. N. J. Magnani. Effects of the Envirunment on the Cracking Behavior of Selected Uranium Alloys. USAEC Report SC-R-722661. 1971. International Corrosion Conference, (Conf720305-2). St. Louis, Missouri. March 20, 1972 .

18. N. J. Magnani. "Effect of Chloride Ions on the Cracking Behavior of U-7.5 Wt Percent Nb-2.5 Wt Percent $\mathrm{Zr}$ and U-4.5 Wt Percent Nb." Journal of Nuclear Materials 42:271. March 19\%"2.

19. J. M. Macki and R. L. Kochen. StressCorrosion Cracking Behavior of the U-4.2 Wt $\% \mathrm{Nb}$ Alloy Aged 80 Hours at $260^{\circ} \mathrm{C}$. USAEC Report RFP-1824. Rocky Flats Division. Dow Chemical U.S.A., Golden, Colorado. March 20, 1972.

20. N. J. Magnani, K. D. Boultinghouse, and C. J. Miglionico. Stress Corrosion Cracking Behavior of U-4.5 Wt Percent Nb in Laboratory Air. USAEC Report SC-RR-710426. Sandia Corporation, Albuquerque, New Mexico. March 1972.

21. J. M. Macki and R. L. Kochen. StressCorrosion Cracking of Underaged and Overaged $U-2.3 \mathrm{Wt}$ Percent $\mathrm{Nb}$ in an Aqueous Chloride Environment. USAEC Report RFP-1904. Rocky Flats Division, Dow Chemical U.S.A., Golden, Colorado. August 4, 1972.

22. N, J, Magnani and H. Romero, Reaction of Water Vapor with U-7.5 Wt Percent Nb-2.5 Wt Percent Zr and U-4.5 Wt Percent Nb. USAEC Report SC-RR-720635. Sandia Corporation, Albuquerque, New Mexico. September 1972.

23. Stress Corrosion Testing (STP 425). American Society for Testing and Materials, Philadelphia, Pennsylvania. 1967. 